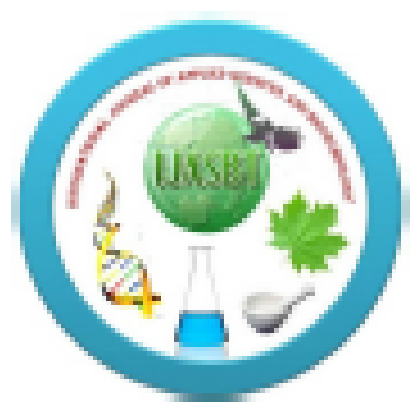

Available online at wwwijasht.org.

International Journal of Applied Sciences and Biotechnology A Rapid Publishing Journal

\begin{tabular}{|c|c|c|}
\hline \multicolumn{2}{|c|}{ APPUED SCENCES } & BIOUECHNOLOSY \\
\hline $\begin{array}{l}\text { Biochemistry } \\
\text { Molecular biology } \\
\text { Microbiology } \\
\text { Cell biology } \\
\text { Cytology } \\
\text { Genetios } \\
\text { Pathalogy } \\
\text { Medicinal chemistry } \\
\text { Polymer sdiences } \\
\text { Analytical chemistry } \\
\text { Natu ral chemistry }\end{array}$ & $\begin{array}{l}\text { Immunobiolosy } \\
\text { Bioliformatics } \\
\text { Novel drug delivery sytem } \\
\text { Pharmacology } \\
\text { Neu roblology } \\
\text { Bio-physics } \\
\text { Botany } \\
\text { Zoology } \\
\text { Allied science } \\
\text { Earth sdience }\end{array}$ & $\begin{array}{l}\text { Microblal biotechnolosy } \\
\text { Med leal biotechnology } \\
\text { Industrial biotechnolosy } \\
\text { Environmental biotechnology } \\
\text { Nanotechnology }\end{array}$ \\
\hline
\end{tabular}

If any queries or feedback, then don't hesitate to mail us at: editor.ijasbtiegmail.com 
DOI:

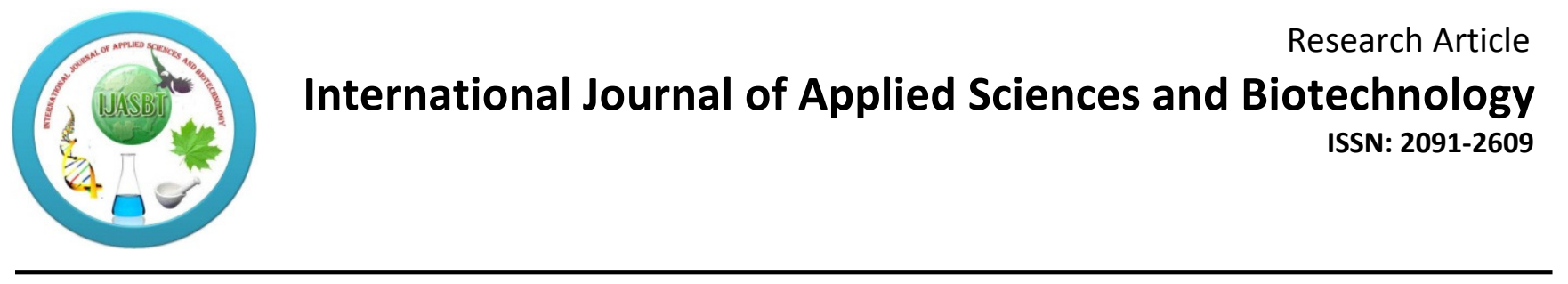

\title{
ANALYSIS OF PHYTOCONSTIUENTS AND CYTOTOXIC ACTIVITIES OF DIFFERENT PARTS OF OCIMUM SANCTUM
}

\author{
Sushika Joshi (Mulmi)* and Anish Kumar Karna \\ Central Department of Chemistry, Tribhuvan University, Kirtipur, Kathmandu, Nepal \\ Corresponding author email: sushikajoshi@gmail.com
}

\begin{abstract}
Phytochemical screening of extracts of Ocimum Sanctum revealed the presence of fatty acids, steroids, triterpenoid, phenolic compound, flavonoid, glycoside, quinines, and carotenoids. $\beta$-sitosterol and Ursolic acid were isolated from leaves of the plant by using column chromatography and identification of these compounds were performed with the help of melting points, Co-TLC and spectroscopic techniques such as IR, ${ }^{1} \mathrm{HNMR}$ and ${ }^{13} \mathrm{CMR}$. GC-MS of hexane fraction showed presence of pentanal, sotolone, hexane-3-one, hexane-2-ol, caryphyllene, benzene 1,2 di-carbolylic acids, isoeugenol, cavracrol and eugenol compounds. The brine shrimp bio assay showed $\mathrm{LC}_{50}$ value 213.7, 97.72 and 21.87 for hexane, ethyl acetate and methanol extracts of leaves respectively, where as $\mathrm{LC}_{50}$ value $169.84,141.25$ and 151.35 for hexane, ethyl acetate and methanol extracts of stem respectively. All extracts are pharmacologically active.
\end{abstract}

Key words: $\beta$-sitosterol, Ursolic acid, spectroscopic techniques, brine shrimp bio assay.

\section{Introduction}

Nepal is rich in all three levels of biodiversity namely species diversity, genetic diversity and habitat diversity. There are thousands of plant species which are known to have medicinal value of the plants, plants extract and their active constituents. Among the 7000 species of medicinal plants recognized all over the world, more than 900 types of precious medicinal plants are found in Nepal (Joshi B. et al. 2011). The plant Ocimum sanctum (Tulsi) is one of the most important species of genus Ocimum which belongs to family Lamiaceae. The plant is widely cultivated in India and Nepal due to its specific aromatic fragrance and medical value. It is considered as the sacred plant in Indian subcontinent. In Aurveda, it has been well documented for its therapeutic potential and described as antiasthmatic and cough suppressant drug (Gupta SK, et al., 2002; Singh N., 2005 \& Xiaorui Z., 2002). It is very valuable medicinal plant for successful management of various diseases like bronchitis, bronchial asthma, dysentry, dyspesia, skin disease, chronic fever, reducing of blood glucose level as well as reduction of total cholesterol in blood (Prakash P. et al., 2005). The plant shows various activities such as good antioxidant, anticancer preventive, antistress, immune modulator, chemo preventive, radio protective, antimicrobial, analgesic, anti-inflammatory antipyretic, antifertility, antidiabetic, anti-thyroid, anti-toxic activity (Singh E et al., 2012 \& Prashar R et al., 1998).

\section{Materials and Methods}

\section{Sample collection and plant extraction}

The fresh leaves and stems of plants were collected from Janakpur, Dhanusha districts of Nepal. The leaves and stems were shade dried and powdered separately. $250 \mathrm{~g}$ of dried powder of leaves and stems were separately subjected to sequential extraction by soxhlet using different solvents such as hexane, ethyl acetate and methanol. The solvent was evaporated under reduced pressure and low temperature to get viscous extract.

\section{Chemical and equipments}

Silica gel (mesh 60-120) was used for column chromatography. Thin-layer chromatography was also performed on silica gel G coated TLC plates of E. Merck Company. Spots were visualised by exposure to iodine vapour, UV radiation and by spraying with cerric sulphate solution. All the solvents used in different experimental process were from E. Merck Company and Qualigen fine chemicals. Melting points were determined by using melting point apparatus from Griffin and George Company Limited. The ${ }^{1}$ HNMR and ${ }^{13} \mathrm{CNMR}$ Spectra were scanned using $400(\mathrm{MHz})$ NMR Spectrophotometer in $\mathrm{CDCl}_{3}$ and with TMS as internal standard. GC-MS analysis was performed on a 
gas chromatography mass spectrometer QP 2010, Shimadzu, Japan. Brine shrimp bioassay was carried out using brine shrimp from Yi Hu Fish farm Trading Pvt. Ltd, Singapore.

\section{Phytochemical Screening}

The phytochemical Screening was carried out according to Prof. I. Ciulei Procedure (Ciulei I., 2082).

\section{Isolation and characterization of compound}

The compound was isolated by using column chromatography and characterized with the help of melting point, CO-TLC, spectroscopic data such as IR, ${ }^{1} \mathrm{HNMR},{ }^{13} \mathrm{CNMR}$ and comparing these data with the authentic sample.

\section{Analysis of Hexane Fraction for GC-MS}

On eluting column with $2 \%$ ethyl acetate in hexane, multiple spots were obtained which was further analyzed from GC-MS.

\section{Brine shrimp bioassay}

The brine shrimp bioassay was carried out according to Mayer et al. procedure (Mayer et al., 1982).

\section{Result and Discussion}

\section{Yield of Extract}

The yields obtained from the leaves and stems are presented in Table 1. The table shows that the polar solvents gave higher yield than non polar solvents.

Table 1: Yields of different solvent extracts

\begin{tabular}{|l|l|l|l|}
\hline $\begin{array}{l}\text { Part } \\
\text { of } \\
\text { Plant }\end{array}$ & Hexane $(\mathrm{g})$ & $\begin{array}{l}\text { Ethyl acetate } \\
(\mathrm{g})\end{array}$ & $\begin{array}{l}\text { Methanol } \\
(\mathrm{g})\end{array}$ \\
\hline Leaf & 8.62 & 12.39 & 25.47 \\
\hline Stem & 4.05 & 7.32 & 12.41 \\
\hline
\end{tabular}

\section{Phytochemical Screening}

The results obtained from the phytochemical screening of leaves and stems of plants are shown in Table 2. The result showed the presence of Tannins, coumarine derivative in leaves extract but not in stem extract and Anthocyanoside, Anthracenoside flavonic glycoside were present in stem extract but not in leaves extract. Phytoconstituents like terpenoid, flavonoids, reducing sugar, fatty acid, glycoside, coumarine etc. were present in both the leaf and stem whereas quinines present only in leaves and carotenoid was present only in stem of the plant.

\section{Isolation and Characterization of Compound}

\section{First Compound}

The compound was isolated from hexane extract by column chromatography with $5 \%$ ethyl acetate in hexane as white needle shaped crystal. Its melting point was found to be $132{ }^{\circ} \mathrm{C}$. It showed positive Salkowski test with reddish color indicating the presence of tetracyclic triterperoid. The compound gave single spot with $20 \%$ Ethyl acetate in hexane on TLC with Rf values 0.45 .

The IR Spectrum showed broad absorption peak at 3425 and $3309 \mathrm{~cm}^{-1}$ indicating the presence of $-\mathrm{OH}$ group. The peak at 2939 and $2870 \mathrm{~cm}^{-1}$ indicated the presence of aliphatic $\mathrm{C}-\mathrm{H}$ stretching. The absorption peak at $1643 \mathrm{~cm}^{-1}$ indicated the unsaturation that is $\mathrm{C}=\mathrm{C}$ absorption peak and peak at $1056 \mathrm{~cm}^{-1}$ indicated the presence of $\mathrm{C}-\mathrm{O}$ stretches. The absorption band at $1485 \mathrm{~cm}^{-1}$ indicated the presence of $\mathrm{C}-\mathrm{H}$ bending of $\mathrm{CH}_{2}$ and absorption band at 1373 and $1348 \mathrm{~cm}^{-1}$ is due to $\mathrm{C}-\mathrm{H}$ bending of gem-dimethyl group. The absorption peak at 965 and $802 \mathrm{~cm}^{-1}$ is due to $\mathrm{C}=\mathrm{C}-\mathrm{H}$ group. The absorption peak at $1242 \mathrm{~cm}^{-1}$ is due to C-C stretching and peak at $725 \mathrm{~cm}^{-1}$ indicated mono substitution in aromatic ring. The IR spectrum of the isolated compound was compared which IR spectrum of authentic sample ( $\beta$-Sitosterol) which are identical and these spectra are shown in Fig. 1.

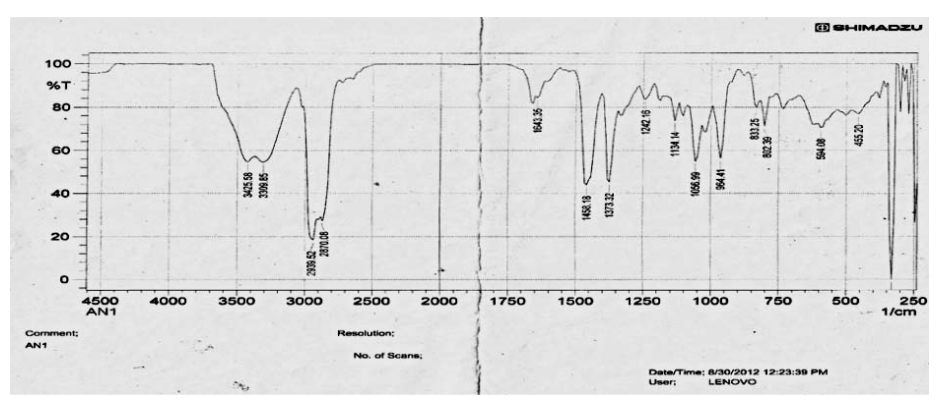

( a)

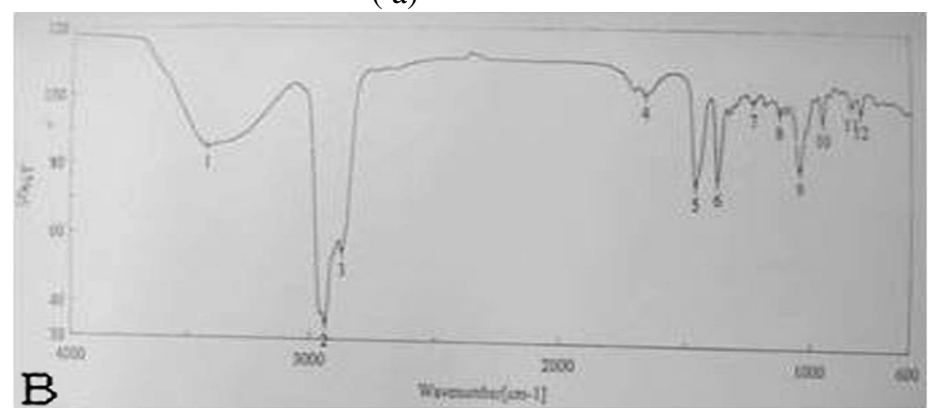

(b)

Fig. 1: The IR spectrum of the isolated compound (a) and IR spectrum of $\beta$-Sitosterol (b) 
S Joshi and AK Karna (2013). Int J Appl Sci Biotechnol, Vol. 1(3): xx-Xx

Table 2: Results of phytochemical screening

\begin{tabular}{|c|c|c|c|c|c|c|c|}
\hline \multirow[t]{2}{*}{ S.N. } & \multirow[t]{2}{*}{ Groups of compound } & \multicolumn{3}{|c|}{ LEAVES } & \multicolumn{3}{|c|}{ STEM } \\
\hline & & Hexane & $\begin{array}{l}\text { Ethyl } \\
\text { Acetate }\end{array}$ & Methanol & Hexane & Ethyl Acetate & Methanol \\
\hline 1. & Fatty acids & + & + & - & + & - & - \\
\hline 2. & Volatiles oils & - & - & & - & - & \\
\hline 3. & Alkaloids & - & - & - & - & - & - \\
\hline 4. & Carotenoids & - & - & - & + & + & \\
\hline 5. & Flavanoids & - & - & - & - & - & - \\
\hline 6. & Emodins & - & - & - & - & - & \\
\hline 7. & Quinones & + & - & + & - & - & - \\
\hline 8. & Coumarins & + & - & + & - & + & \\
\hline 9. & Sterols and Triterpenes & + & + & - & + & + & - \\
\hline 10. & Tannins & - & + & + & - & + & - \\
\hline 11. & Glycosides & + & - & + & - & - & + \\
\hline 12. & Reducing compounds & - & - & + & - & - & + \\
\hline 13. & Anthocyanosides & - & - & - & - & - & + \\
\hline 14. & Polyoses & - & - & - & - & - & - \\
\hline 15. & Saponins & - & - & - & - & - & - \\
\hline 16. & Anthracenosides & - & - & - & - & - & + \\
\hline 17. & Flavone Glycoside & - & - & - & - & - & + \\
\hline
\end{tabular}

The ${ }^{1}$ HNMR spectrum of compound displayed two singlets at $\delta 1.00$ and $\delta 0.66$ indicated the methyl proton of C-19 and C-18 respectively. The proton NMR spectrum also exhibited one olefinic double bond proton (C-6) as a doublet at $\delta 5.33$.Other multiplets at $\delta 3.51$ equivalent to singlet proton was assigned for the proton of C-3. Two upfield signals also doublet at $\delta 0.80$ and $\delta 0.78$ respectively due to presence of secondary methyl group at position C-26 and C-27 of skeleton representing the presence of isopropenyl group. The very upfield chemical shift at $\delta 0.82$ as a triplet was assigned for terminal methyl group of C-29. Similarly, other upfield chemical shift at $\delta 0.94$ as a doublet was assigned for methyl group at position C-21 of molecular structure. Three multiples equivalent to two protons each appeared at $\delta 1.83, \delta 1.97$ and $\delta 2.26$ were assigned for $3 \mathrm{CH}_{2}$ group. The remaining protons have appeared at a range of $\delta 1.01$ to $\delta 1.7$. The weak signal of chemical shift at $\delta 5.1(\mathrm{~m})$ and $5.12(\mathrm{~m})$ were also obtained due to mixture of stigma sterol. The ${ }^{1}$ HNMR spectrum of the isolated compound was compared which ${ }^{1} \mathrm{HNMR}$ spectrum of authentic sample $(\beta-$ Sitosterol) which are identical and these spectra are shown in Fig. 2.

The ${ }^{13}$ CNMR spectra of the compound revealed the presence of 29 carbons. The chemical shift at $\delta 140.75 \mathrm{ppm}$ and $\delta 121.70 \mathrm{ppm}$ represented carbons of alkene conjugated that is C5 and C6 carbon. Similarly, the chemical shift at $\delta 71.810 \mathrm{ppm}$ represented $\mathrm{C}_{3}$ carbon due to presence of $\mathrm{OH}$ group at this position. The chemical shift at $\delta 20.01 \mathrm{ppm}$ and $23.12 \mathrm{ppm}$ represented the $\mathrm{C} 18$ and $\mathrm{C} 19$ angular carbon.

The chemical shift at $\delta 138.29$ and $\delta 129.27$ represent the conjugation which was due to possibility of mixture of stigmasterol. The value of ${ }^{13} \mathrm{CNMR}$ spectrum of the isolated compound was identical with $\beta$-Sitosterol compound which is shown in Fig. 3.

Thus on the basis of melting points, CO-TLC, IR, ${ }^{1} \mathrm{HNMR},{ }^{13} \mathrm{CNMR}$ data and comparison of these data with literatures (Bag et al., 2012, Arjun et al., 2010 and Anooj K et al., 2010) the isolated first compound was identified as $\beta$-sitosterol. The structure of this compound is shown in Fig. 4. 
S Joshi and AK Karna (2013). Int J Appl Sci Biotechnol, Vol. 1(3): xx-xx

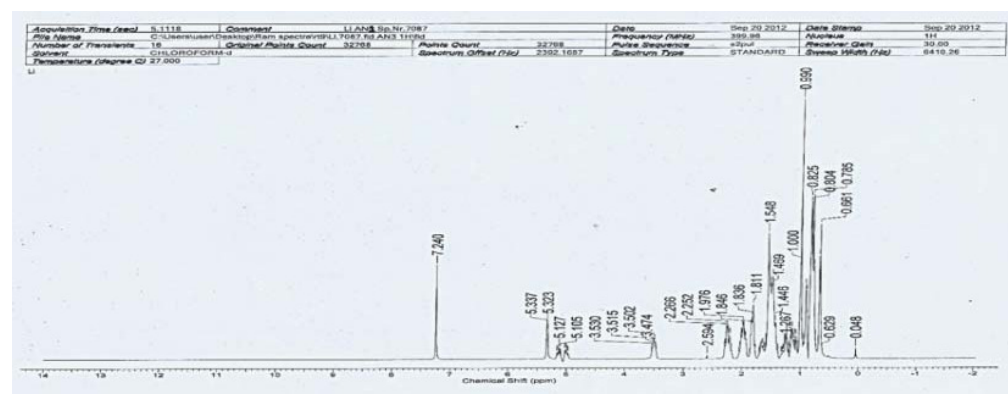

(a)

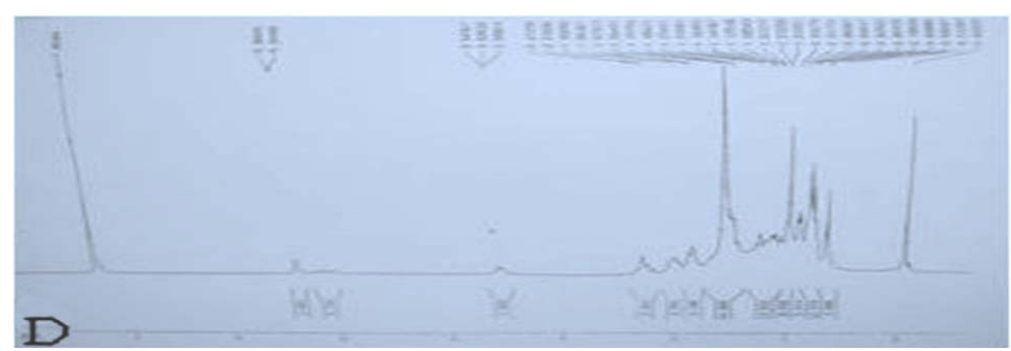

(b)

Fig. 2: The ${ }^{1}$ HNMR spectrum of the isolated compound (a) and ${ }^{1}$ HNMR spectrum of $\beta$-Sitosterol (b).

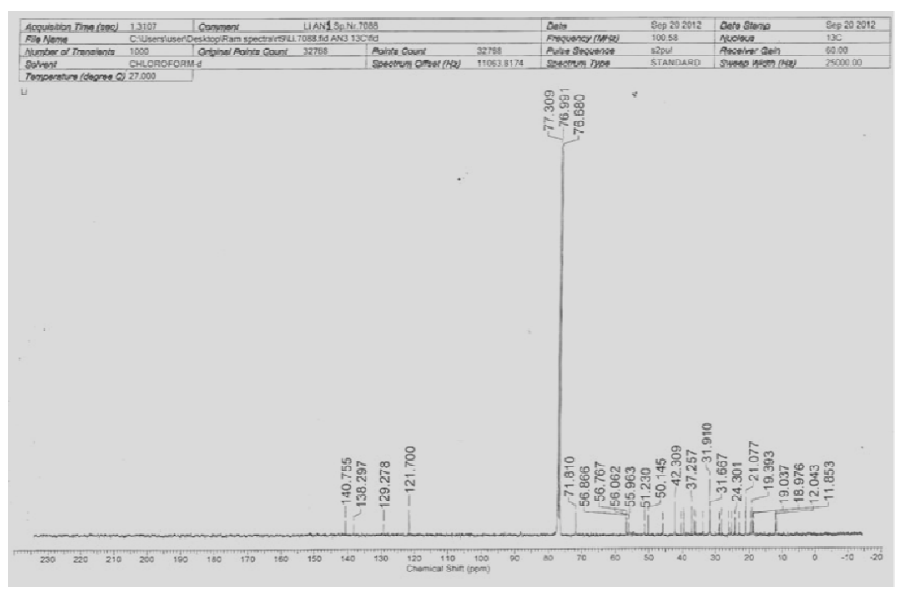

Fig. 3: ${ }^{13}$ CNMR spectrum of the isolated compound sample ( $\beta$-Sitosterol)

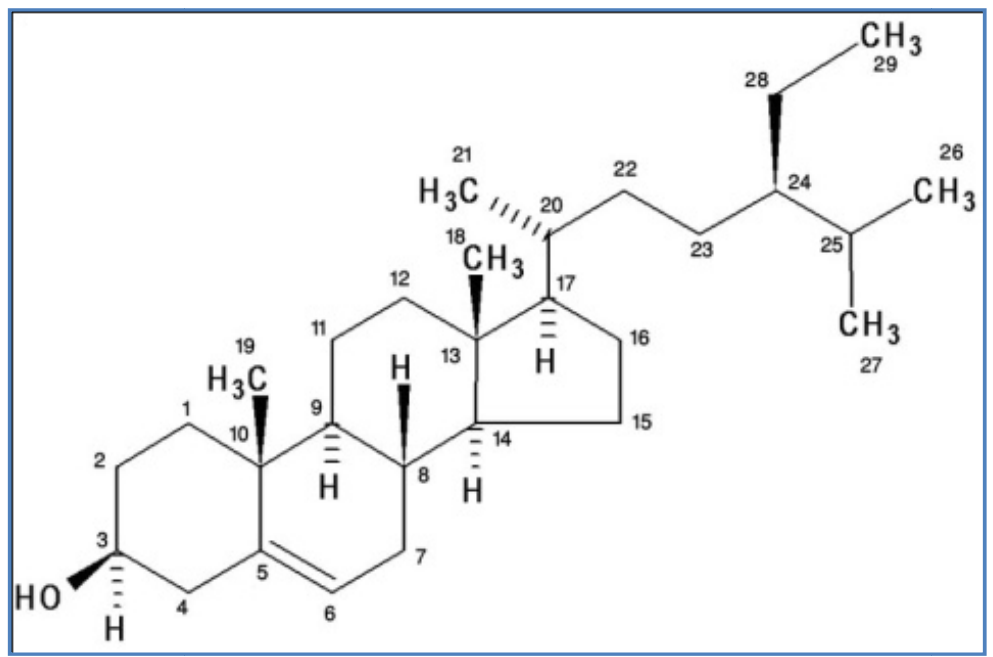

Fig. 4: Structure of $\beta$-sitosterol 


\section{Second compound}

The compound was obtained from hexane extract by column chromatography with $10 \%$ ethylacetate in hexane as colourless crystal having m.pt.225 ${ }^{\circ} \mathrm{C}$. It showed effervescences with sodium bicarbonate solution. It also gave positive salkowski test with reddish colour indicating the presence of triterpenoid. The compound gave single spot showed with $\mathrm{Rf}$ values 0.64.in $30 \%$ ethyl acetate in hexane.

The IR spectrum displayed characteristics absorption band for hydroxyl group at $3425 \mathrm{~cm}^{-1}$. The absorption peak at $2654 \mathrm{~cm}^{-1}$ and $1689 \mathrm{~cm}^{-1}$ indicated the presence of carboxyl group. The absorption band at $1033 \mathrm{~cm}^{-1}$ and $996 \mathrm{~cm}^{-1}$ indicated the $-\mathrm{C}-\mathrm{OH}$ band and another peak at 2939 and $2870 \mathrm{~cm}^{-1}$ indicated the presence of aliphatic C-H stretching. The IR spectrum of the isolated compound compared with IR spectrum of authentic sample (Ursolic acid) which are identical and shown in Fig. 5.

The ${ }^{1}$ HNMR spectrum of the compound showed one proton broad signal at $\delta 5.26$ assigned to vinylic $\mathrm{H}-12$ protons. One proton double doublets (triplet) at $\delta 3.214$ assigned to $\alpha$-oriented carbinol H-3 proton. One proton doublet at $\delta 2.789$ was ascribed to $\mathrm{C}-18$ proton. Five three proton broad signal at $\delta 0.86,0.70,1.113,0.966$, 1.1 were associated correspondingly with tertiary C-23, C-24, C-25, C-26, C-27 methyl protons respectively and three proton doublets at $\delta 0.75$ and 0.908 corresponds to C-29 and C-30 methyl protons. The remaining methane and methylene protons resonated from $\delta 2.60$ to 1.23 . The ${ }^{1} \mathrm{HNMR}$ spectrum of the isolated compound and ${ }^{1} \mathrm{HNMR}$ spectrum of authentic sample (Yamaguchi H. et al., 2008) are shown in Fig. 6.

The ${ }^{13}$ CNMR spectrum of compound displayed 30 carbons atoms and important signals appeared for carboxyl group at $\delta 182.92 \mathrm{ppm}$ (C-28). The chemical shift at $\delta 143.57$ and $\delta 122.625$ represented carbons of alkene conjugated that is $\mathrm{C}-12$ and $\mathrm{C}-13$ carbon. The chemical shift at $\delta 79.008$ represented carbinol carbon that is $\mathrm{C}-3$ carbon. The ${ }^{13} \mathrm{CNMR}$ spectrum of the isolated compound compared with ${ }^{13} \mathrm{CNMR}$ spectrum of authentic sample (Ursolic acid), which are identical and shown in Fig. 7.

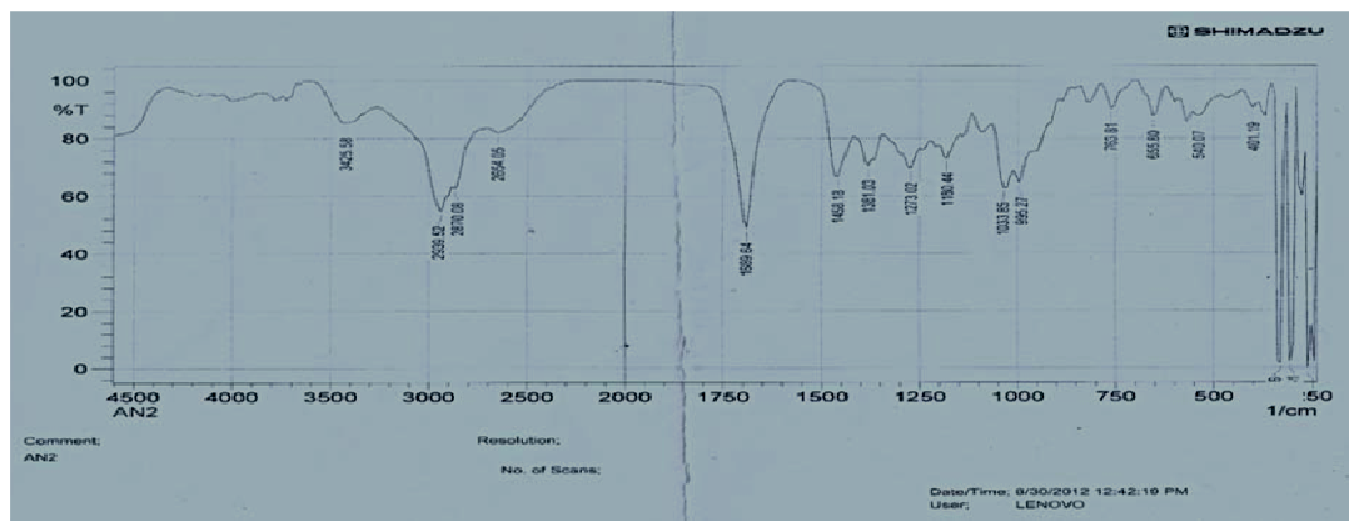

(a)

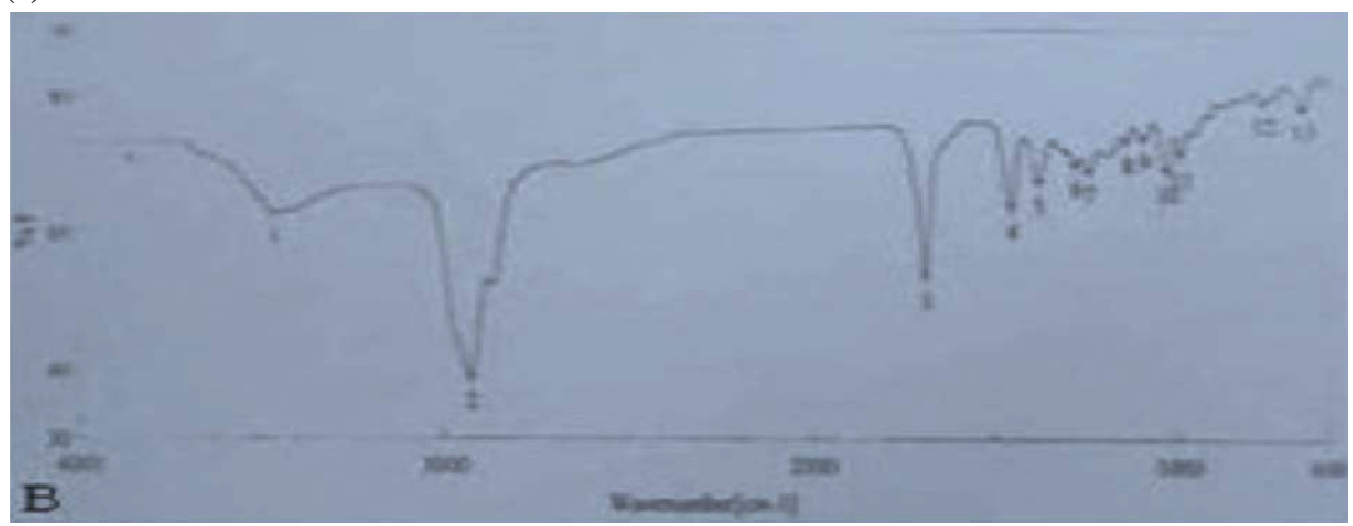

(b)

Fig. 5: The IR spectrum of the isolated compound (a) and IR spectrum of Ursolic acid (b). 

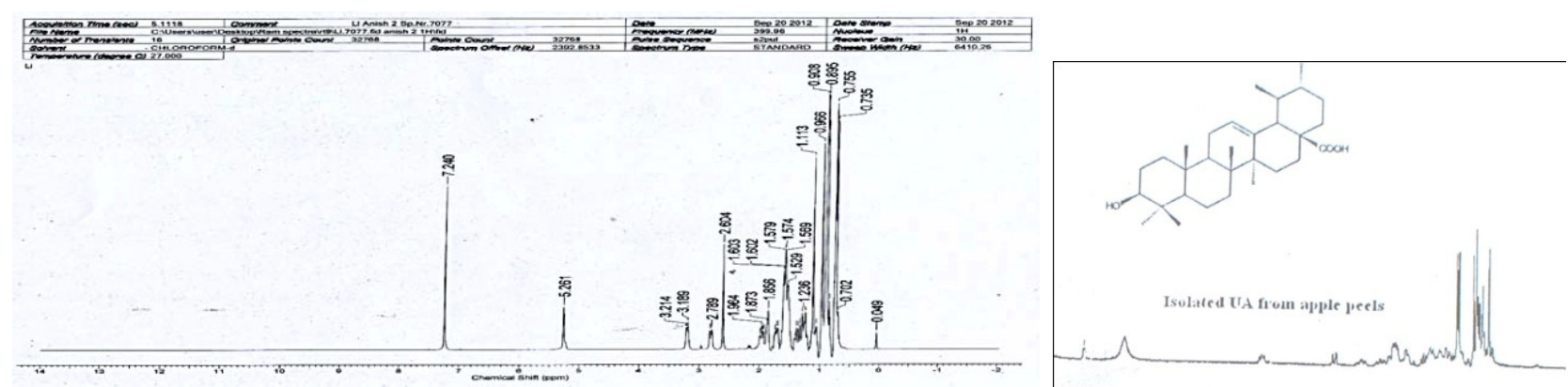

(a)

(b)

Fig. 6: The ${ }^{1}$ HNMR spectrum of the isolated compound (a) and ${ }^{1}$ HNMR spectrum of Ursolic acid (b).

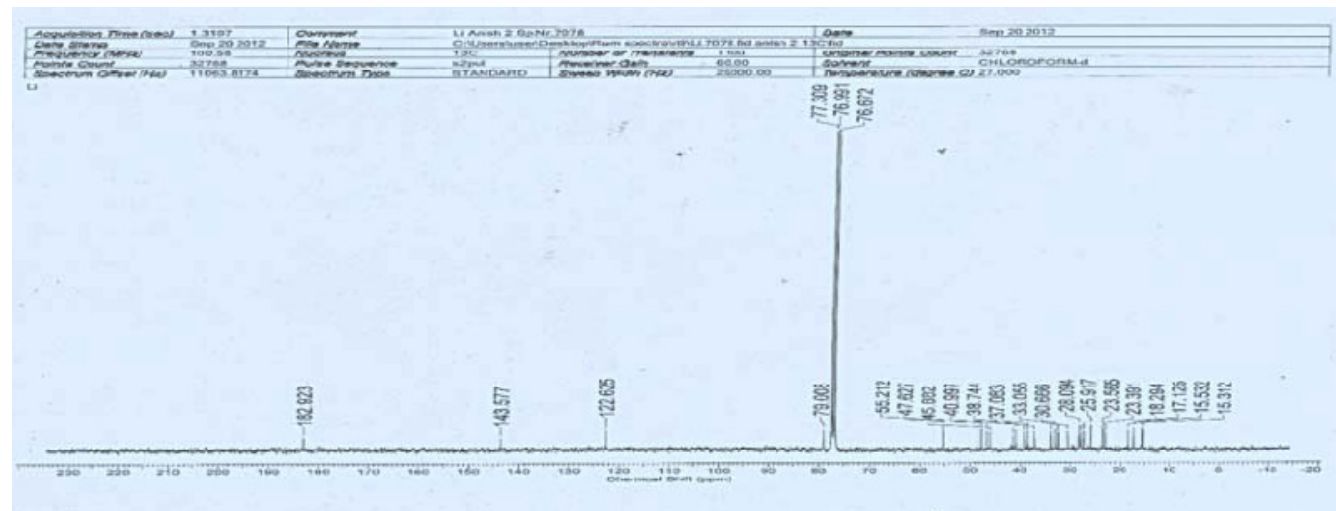

(a)

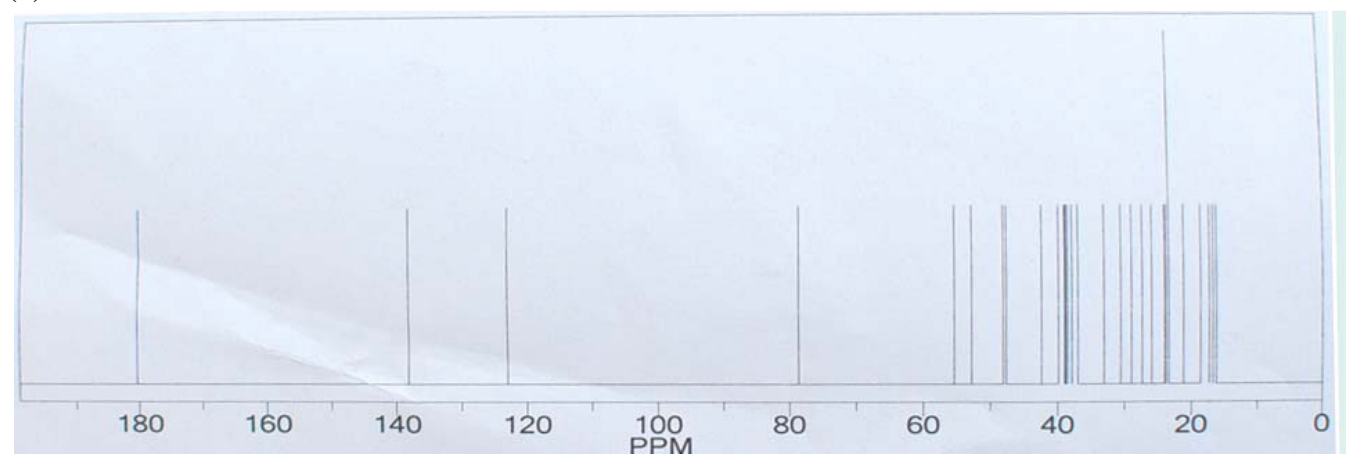

(b)

Fig. 7: The ${ }^{13}$ CNMR spectrum of the isolated compound (a) and ${ }^{13} \mathrm{CNMR}$ spectrum of Ursolic acid (b).

Thus, on the basis of melting points, IR, ${ }^{1} \mathrm{HNMR},{ }^{13} \mathrm{C}-$ NMR spectral data and comparison of these data with authentic sample, the compound was identified as Ursolic Acid. The structure of Ursolic acid is shown in Fig. 8.

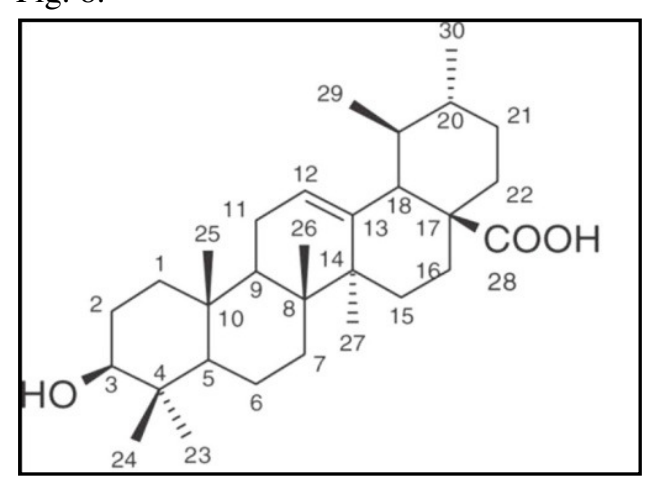

Fig. 8: The structure of Ursolic acid

\section{Analysis of GC-MS Spectrum of Hexane Fraction}

The fraction obtained from column with $2 \%$ ethyl acetate in hexane was further analyzed by GC-MS qualitatively, which are shown in Fig. 9. The spectra revealed the presence of 9 compounds such as pentanal, sotolone, hexane-3-one, hexane-2-ol, caryphyllene, benzene 1,2 dicarbolylic acids, isoeugenol, cavracrol and eugenol, which are given in Table 3.The compounds isoeugenol, cavracrol, Benzene1,2 dicarbolylic acids and eugenol were found to be major compounds in this fraction. 
S Joshi and AK Karna (2013). Int J Appl Sci Biotechnol, Vol. 1(3): xx-Xx

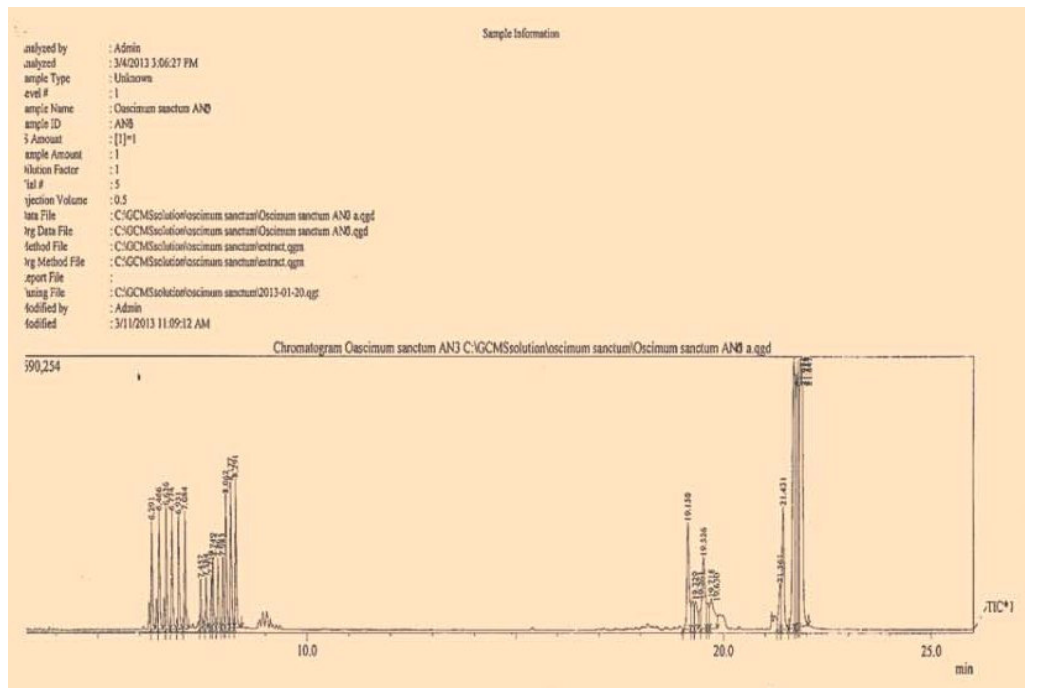

Fig. 9.GC-MS spectrum of $2 \%$ ethyl acetate in hexane.

Table 3: GC-MS Spectrum of 2\% of ethyl acetate in hexane fraction

\begin{tabular}{|c|c|c|c|c|}
\hline S.N & RT & COMPOUND & MW & Area (\%) \\
\hline 1 & 8.602 & Pentanal & 86 & 4.82 \\
\hline 2 & 8.177 & sotolone & 112 & 4.92 \\
\hline 3 & 19.150 & Hexane-3-one & 100 & 7.09 \\
\hline 4 & 19.526 & Hexane-2-ol & 102 & 6.22 \\
\hline 5 & 21.431 & Caryophyllene & 162 & 7.70 \\
\hline 6 & 21.681 & Benzene 1,2 di-carboxylic acids & 166 & 16.33 \\
\hline 7 & 21.716 & Isoeugenol & 164 & 12.32 \\
\hline 8 & 21.784 & Cavracrol & 150 & 14.06 \\
\hline 9 & 21.841 & Eugenol & 164 & 26.55 \\
\hline
\end{tabular}

\section{Brine Shrimp Bioassay}

The Brine Shrimp bio assays of leaves showed that $\mathrm{LC}_{50}$ values of hexane, ethyl acetate and methanol fractions were $213.79,97.72$ and 21.87 respectively. The Brine Shrimp bioassay of stem showed that $\mathrm{LC}_{50}$ values of hexane, ethyl acetate and methanol fractions $169.84,141.25$ and 151.35 respectively. Among the entire fraction, methanol fraction of leaves showed lowest $\mathrm{LC}_{50}$ value and ethyl acetate fraction of stem showed lowest $\mathrm{LC}_{50}$ value. However, all the fractions were found to be bioactive.

\section{Acknowledgement}

The authors are thankful to Central Department of Chemistry, Tribhuvan University, Kirtipur, Nepal for providing us the research facilities to conduct this research work. The authors also express their gratitude to Department of Chemistry, Martin Luther University, Halle-Wittenberg, Germany for providing us NMR Spectra.

\section{Rererences}

Anooj K and Ajay KS (2010) Isolation of Stigmasterol and $\beta$-sitosterol from petroleum ether extract of aerial parts of Ageratum Conyzoides. IJPPS. 3: 94-96.

Arjun P, Jha S, Murthy PN, Manik and Sharone A (2010) Isolation and characterization of stigmast5 -en-3 $\beta$-ol( $\beta$-sitosterol) from the leaves of Hygrophila Spinosa T. Anders IJPSR, 1(2), 95100.

Bag P, Chattopadhyay D, Mukherjee H, Ojha D, Mandal N, Sarkar MC, Chatterjee T, Das G and Chakraborti S (2012) Anti-herpes virus activities of bioactive fraction and isolated pure constituent of Mallotus peltatus; an ethnomedicine from Andaman Islands. Virology J., 9:98.

Ciulei I (1982) Methology for analysis of vegetable drugs, Practical manuals on industrial utilization 
S Joshi and AK Karna (2013). Int J Appl Sci Biotechnol, Vol. 1(3): xx-Xx

of medicinal and aromatic plant, Bucharest, 73p.Phytochemistry 63(1): 97-104

Gupta SK, Jai Prakashan and Srivastav S. (2002) Validation of Traditional Clam of Tulsi, Ocimum Sanctum Linn, as a Medicinal Plant.. Indian J. Exp. Biol. 40:765-773.

Joshi B, Sah GP, Basnet BB, Bhatt MR, Sharma D, Subedi K, Pandey J and Mall R (2011) Phytochemical extraction and antimicrobial properties of different medicinal plants: Ocimum sanctum (Tulsi), Eugenia caryophyllata (clove), Arhyranthes bidentata (Datiwan) and Azadirachta indica (Neem). Journal of Microbiology and Antimicrobials 3(1): 1-7.

Mayer BN, Ferrigni R, Douthana NR, Jacobsen JG, Nichols LB and Mclaughlin JK (1982) Brine Shrimp Bioassay, a convenient bioassay for active plant constituents. Planta Medica 45:31-34.

Prakash P and Gupta N. (2005) Therapeutic uses of Ocimum sanctum Linn (Tulsi) with a note on Eugenol and its pharmacological actions: A short review. Indian J. Physiol Pharmacol 49(2): 125131.
Prashar R, Kumar A, Hewer A, Cole KJ, Davis W, Phillips DH (1998) Inhibition by an extract of Ocimum sanctum of DNA-binding activity of 7.12-dimethylbenz $[\alpha]$ anthracene in rat hepatocytes in vitro. Cancer Lett. 128(2): 155160.

Singh E, Sharma S, Dwivedi J and Sharma S. (2012) Diversified potentials of Ocimum sanctum Lin (Tulsi): An exhaustive survey J. Nat. Prod. Plant Resour. 2(1):39-48.

Singh N (2005) In the symposium "Continuing Education program on Herbal drug research" held at institute of Nuclear medicine and allied science, DRDO, Delhi, India, Oct 3-7.

Xiaorui Z (2002) WHO Monogram on Selected Medicinal Plants. 2: 206-216.

Yamaguchi H, Noshita T, Kidachi Y, Umetsu H, Hayashi M, Komiyama K, Funayama S and Ryoyama K (2008) Isolation Ursolic Acid from Apple Peels and Its Specific Efficacy as a Potent Anitumor Agent, Journal of Health Science 54(6): 654-660. 